\title{
Delineation of the recharge areas and distinguishing the sources of karst springs in Bringi watershed, Kashmir Himalayas using hydrochemistry and environmental isotopes
}

\author{
NADEem A Bhat* and Gh JeElani \\ Department of Earth Sciences, University of Kashmir, Srinagar 190 006, India. \\ *Corresponding author. e-mail: mnadeem83@gmail.com
}

\begin{abstract}
Water samples were collected from precipitation, streams and karst springs of the mountainous Bringi catchment of Kashmir Himalayas for major ions, stable isotopes $\left(\delta^{18} \mathrm{O}\right.$ and $\left.\delta \mathrm{D}\right)$ and ${ }^{3} \mathrm{H}$ analysis. The main objective is to identify the potential recharge area for karst springs. The water in the Triassic limestone aquifer of the Bringi watershed is characterized by low levels of mineralization with TDS of the spring water samples ranging between 99 and $222 \mathrm{mg} / \mathrm{l}$ except the Kongamnag spring, which contained TDS up to $425 \mathrm{mg} / \mathrm{l}$. As expected in an area with dominant carbonate lithology, $\mathrm{Ca}-\mathrm{HCO}_{3}$ and $\mathrm{Ca}-$ $\mathrm{Mg}-\mathrm{HCO}_{3}$ hydrochemical facies were found. Based on the amount weighed monthly averages $(n=6)$, the local meteoric water line (LMWL) for Bringi watershed is $\delta \mathrm{D}=7.7 \times \delta^{18} \mathrm{O}+11.1\left(r^{2}=0.99\right)$. The isotopic signature of winter precipitation is reflected in stream and spring water in late spring and is therefore, a representative of snow melting. The spring waters in September bear the $\delta^{2} \mathrm{H}$ and $\delta^{18} \mathrm{O}$ enriched isotopic signatures of summer rainfall. With the help of the local vertical isotopic gradient of precipitation $\left(\delta^{18} \mathrm{O}=-0.27 \%\right.$ per $100 \mathrm{~m}$ increase in elevation), the mean elevation of precipitation that recharged the aquifer is estimated and ranges about $2500-2900 \mathrm{~m}$ amsl. There is a very strong correlation $\left(r^{2}=0.97\right)$ between the seasonal isotope composition of streams and springs, indicating that streams and springs either share similar catchments or the springs are recharged by the streams.
\end{abstract}

\section{Introduction}

Although the valley of Kashmir has abundant water resources in the form of glaciers, lakes, rivers and springs, yet great concern is expressed for the supply of water for domestic and agricultural purposes, particularly in upland catchments of the Jhelum River (Bhat et al. 2014; Jeelani et al. 2014). Among the catchments, the Bringi watershed is dominantly a karst terrain, where there is an exchange of water between streams and springs (Ford and Williams 1989). The karst springs are recharged by the catchment streams at different elevations (Jeelani et al. 2014). However, due to increase in population and infrastructure, there has been expansion of villages more towards the mountainous regions, where the recharge sites of the springs are located. Because of the highly porous karst environment, the region has been prone to dumping of solid and liquid wastes accompanied with an 'out of sight, out of mind' mentality. It is worth mentioning that karst environments lack the effective attenuation mechanism of impervious aquifers, where breakdown of contaminants by micro-organisms and by physical and chemical processes is very weak (Ford and Williams 1989).

Keywords. Karst springs; hydrochemistry; isotopes; Bringi watershed; Kashmir Himalayas. 
Thus, any contamination near recharge areas can lead to degradation of water quality in areas of discharge (streams and springs) (Abbott et al. 2000; Jeelani et al. 2014).

Keeping in mind these concerns, it is important to delineate the potential recharge sites in order to prevent or at least reduce future contamination. There are a number of approaches that have been used to study the hydrological processes of karst environments (Gat 1971; Ford and Williams 1989; Agarwal et al. 2006). Environmental isotopes $\left({ }^{2} \mathrm{H},{ }^{18} \mathrm{O}\right.$ and $\left.{ }^{3} \mathrm{H}\right)$ in conjunction with conventional hydrogeology and hydrogeochemistry were proven to be effective tools for solving many critical hydrological problems (Clark and Fritz 1997). The meteoric water at a specific location has a characteristic isotopic signature (Gat 1971; Clark and Fritz 1997; Lee et al. 1999; Price and Swart 2006) serve as a basis for delineating the recharge areas of groundwater/spring water (Fontes et al. 1967; Gonfiantini et al. 1976; Jeelani et al. 2010). Seasonal fluctuations in stable isotope values have been used to quantify infiltration rates and to identify the primary recharge seasons (Abbott et al. 2000; McConville et al. 2001; O'Driscoll et al. 2005).

\section{Study area}

Bringi watershed, one of the upland catchments of the Jhelum River in Kashmir Himalayas, lies between $33^{\circ} 20^{\prime}-33^{\circ} 45^{\prime} \mathrm{N}$ and $75^{\circ} 10^{\prime}-75^{\circ} 30^{\prime} \mathrm{E}$ (figure 1) and covers an area of approximately $595 \mathrm{~km}^{2}$. The elevation of the mountainous catchment ranges from $1650 \mathrm{~m}$ above mean sea level (amsl) at Achabal to more than $4000 \mathrm{~m}$ amsl near Sinthan top. The watershed is drained in part by the Bringi stream. The area has a temperate type of climate with a mean annual temperature of about $12^{\circ} \mathrm{C}$ and characterized by marked seasonality with four well-defined seasons: spring (March-May), summer (June-August), autumn (September-November) and winter (DecemberFebruary). The area receives a mean annual precipitation amount of about $1150 \mathrm{~mm}$, with a maximum during winter and spring in the form of snow and rain and minimum precipitation during autumn (Jeelani et al. 2014).

The Bringi watershed is dominated by Panjal Traps and Triassic Limestone formations, but also include Paleozoic sedimentary rock and recent alluvium deposits (Middlemiss 1910; Coward et al. 1972; Wadia 1975). Upper Paleozoic rocks, lava,

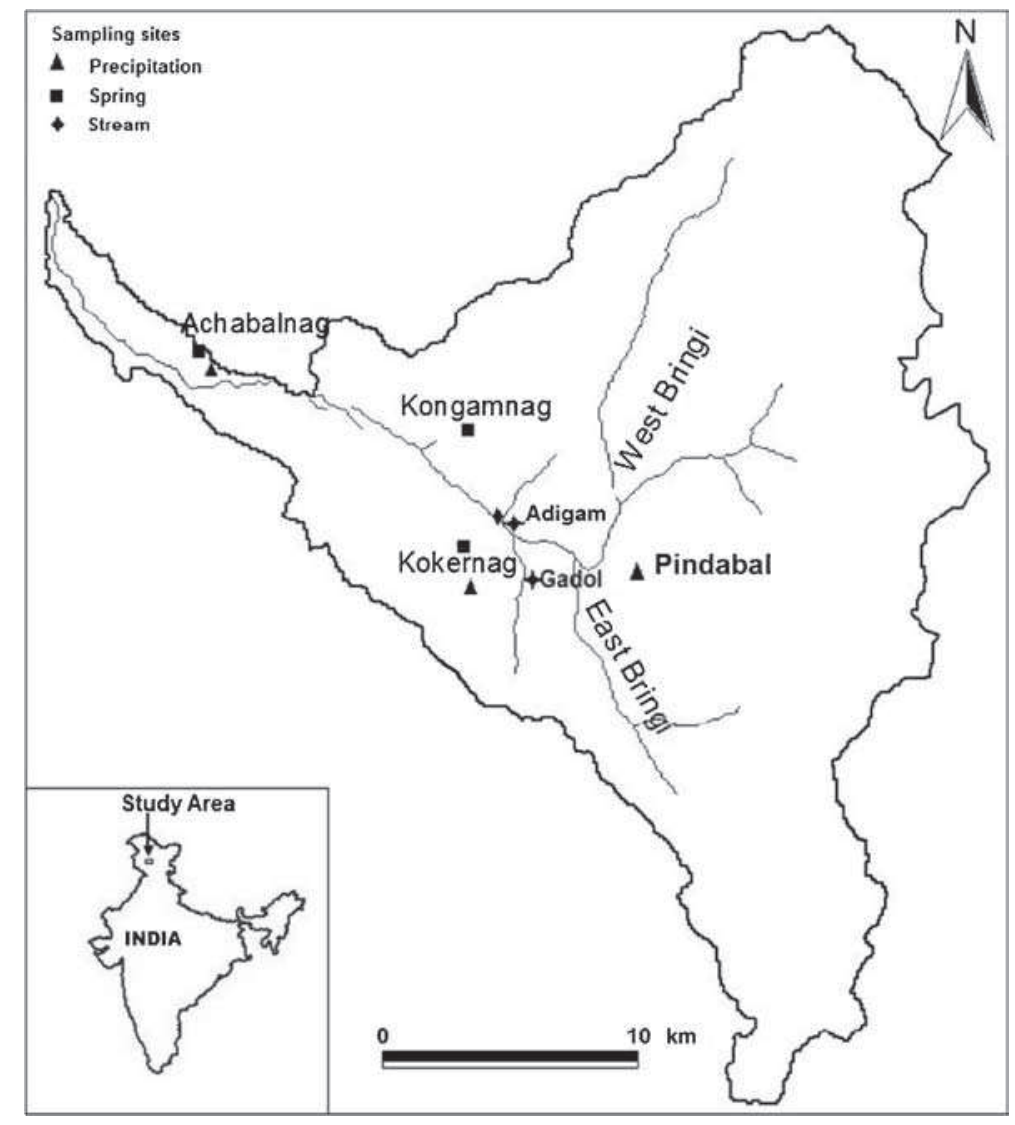

Figure 1. Location map of Bringi watershed showing sampling sites. 
pyroclasts and arenites are only marginal to study area. The Triassic Limestone Formation is more than $1000 \mathrm{~m}$ thick sequence and contains several horizons of shale and sandstone. The Karewa Group of rocks are the fluvio-lacustrine deposits that overlie the limestones and contain unconsolidated material like light grey sands, dark grey clays, coarse- to fine-grained sand, gravel, marl, silt, varved clays, brown loam lignites, etc. The alluvial deposits represent recent sediments and contain silt and mud, though active flood plains are mainly of coarse gravel and boulders. Groundwater discharge occurs through the springs, primarily the Achabalnag, Kokernag and Kongamnag, hosted by the Triassic Limestone (Jeelani 2008). Relatively speaking, Achabal and Kokernag springs are cold $\left(8^{\circ}-14^{\circ} \mathrm{C}\right)$ and Kongamnag is warm $\left(14^{\circ}-19^{\circ} \mathrm{C}\right)$. The warm temperature of Kongamnag may be attributed to deeper circulation of the infiltrating water. However, the lower temperature in March and May $\left(\sim 14^{\circ} \mathrm{C}\right)$ reflects the mixing of snow melt. The discharge rate of the cold springs is highly variable. The discharge of Achabal ranges from $160 \mathrm{l} / \mathrm{s}$ in winter to about $3000 \mathrm{l} / \mathrm{s}$ in summer and the flow of Kokernag ranges from 600 to about $8000 \mathrm{l} / \mathrm{s}$. The highly fluctuating nature of the discharge and the rapid response of the spring flows to rainfall and snow melting is a function of karst landscape. The flow of Kongamnag ranges from 12 to $20 \mathrm{l} / \mathrm{s}$ with higher discharge being observed in spring and summer seasons.

\section{Methods}

Water samples from three precipitation sites (Achbal, Kokernag, Pindabal), one stream (Bringi) and three springs (Achabalnag, Kokernag, Kongamnag) were collected every two months across the Bringi watershed (figure 1) for one hydrological cycle for major ion $\left(\mathrm{Ca}^{2+}, \mathrm{Mg}^{2+}\right.$, $\left.\mathrm{Na}^{+}, \mathrm{K}^{+}, \mathrm{HCO}_{3}^{-}, \mathrm{Cl}^{-}, \mathrm{SO}_{4}^{2-}, \mathrm{SiO}_{2}, \mathrm{NO}_{3}^{-}, \mathrm{F}^{-}\right)$and isotopic $\left(\delta^{18} \mathrm{O}, \delta^{2} \mathrm{H}\right.$ and $\left.{ }^{3} \mathrm{H}\right)$ analyses following the standard procedures (Clark and Fritz 1997; APHA 1998). For the stable isotopes, precipitation samples were collected in standard precipitation collectors, consisting of a 20-1 plastic container fitted with a funnel and a long narrow tube to avoid evaporation. Stream water samples were collected upstream before the confluence of the streams and spring water samples were collected at the source. For tritium, the samples were collected from one precipitation site, one stream and three springs in 1 liter HDPE bottles in January/March and July/September 2008.

Parameters such as water temperature, $\mathrm{pH}$ and electric conductivity (EC) were measured in situ. For major ion analysis, the samples were filtered through $<0.45 \mu \mathrm{m}$ nucleopore filter paper to separate the suspended sediments. Major ion analysis was done in the Hydrogeology Laboratory, Department of Earth Sciences, University of Kashmir, Srinagar. $\mathrm{Ca}^{2+}$ and $\mathrm{Mg}^{2+}$ were determined by EDTA titration using murexide as indicator, whereas the $\mathrm{Cl}^{-}$was determined by titration with $\mathrm{AgNO}_{3}(0.02 \mathrm{~N})$ using potassium chromate (5\%) as an indicator. $\mathrm{HCO}_{3}^{-}$was determined by titration of the water sample against $\mathrm{HCl}(0.01 \mathrm{~N})$ in which methyl orange was used as an indicator. The $\mathrm{Na}^{+}$ and $\mathrm{K}^{+}$concentration in the samples were determined by using flame emission photometer. $\mathrm{SO}_{4}^{2-}$, $\mathrm{SiO}_{2}^{-}$and $\mathrm{NO}_{3}^{-}$were determined by UV-VIS spectrophotometer. $\delta^{18} \mathrm{O}$ analysis was carried out at the Isotope Application Division, Bhaba Atomic Research Centre (BARC), Mumbai, using Isotope Ratio Mass Spectrometer (Geo 20-20, Europa) by gas equilibration method (Epstein and Mayeda 1953). Hydrogen isotopic analyses were carried out using a dual-inlet isotope ratio mass spectrometer (Isoprime) at the National Institute of Hydrology (NIH), Roorkee. The stable isotope results of oxygen and hydrogen are reported relative to Vienna Standard Mean Ocean Water (VSMOW) (Gonfiantini 1981). The precision of the measurement of $\delta^{18} \mathrm{O}$ and $\delta \mathrm{D}$ was $\pm 0.1 \%$ and $\pm 1.0 \%$, respectively. ${ }^{3} \mathrm{H}$ analysis was carried out at the Low Level Laboratory, BARC, Mumbai, using a liquid scintillation counter (Quantulus 1220 PerkinElmer) after electrolytic enrichment of samples. The accuracy of the tritium measurement was $0.5 \mathrm{TU}(1 \sigma)$. The discharge of the springs and streams was measured using the velocityarea method. Precipitation and temperature data of Kokernag station was collected from Indian Meteorological Department (IMD), Srinagar.

\section{Results and discussion}

The statistical overview of the results of physicochemical parameters of stream and spring samples is presented in table 1.

\subsection{Physical parameters ( $p H$ and $T D S$ )}

All the stream and spring water samples were alkaline in nature ( $\mathrm{pH}$ : 7-8.2) with the highest values observed during winter and lowest during late spring. The total dissolved solids $(\mathrm{TDS}=\mathrm{Ca}+$ $\mathrm{Mg}+\mathrm{Na}+\mathrm{K}+\mathrm{HCO}_{3}+\mathrm{SO}_{4}+\mathrm{Cl}$ in $\left.\mathrm{mg} / \mathrm{l}\right)$ of the streams showed a narrow range (107-119 mg/l) except in winter $(\sim 161 \mathrm{mg} / \mathrm{l})$ when the stream flow is dominantly contributed from the base-flow. The water in the Triassic limestone aquifer of Bringi watershed is characterized by low levels of 
Table 1. Summary of physico-chemical analysis of the stream and spring water samples of Bringi watershed.

\begin{tabular}{|c|c|c|c|c|c|c|c|c|c|}
\hline \multirow[b]{2}{*}{ Parameter } & \multicolumn{3}{|c|}{ Stream } & \multicolumn{3}{|c|}{ Springs (cold) } & \multicolumn{3}{|c|}{ Spring (warm) } \\
\hline & Mean & Min & $\operatorname{Max}$ & Mean & Min & $\operatorname{Max}$ & Mean & Min & $\operatorname{Max}$ \\
\hline Elevation (m) & 2110 & 2110 & 2210 & 1773 & 1656 & 1890 & 1922 & 1922 & 1922 \\
\hline Temperature $\left({ }^{\circ} \mathrm{C}\right)$ & 12.1 & 9.0 & 14.5 & 11.7 & 8.2 & 14.4 & 15.6 & 13 & 19 \\
\hline $\mathrm{pH}$ & 7.9 & 7.8 & 8.1 & 7.6 & 7 & 8.2 & 7.35 & 7.1 & 7.6 \\
\hline $\mathrm{EC}(\mu \mathrm{s} / \mathrm{cm})$ & 170 & 140 & 239 & 235 & 142 & 326 & 475 & 442 & 530 \\
\hline $\operatorname{TDS}(\mathrm{mg} / \mathrm{l})$ & 121 & 107 & 161 & 161 & 99 & 222 & 357 & 307 & 425 \\
\hline Calcium (mg/l) & 39.7 & 35 & 45 & 54.4 & 29 & 80 & 115 & 90 & 146 \\
\hline Magnesium (mg/l) & 3.4 & 1.0 & 9.7 & 6.4 & 3.9 & 10.2 & 17.41 & 11.7 & 20.4 \\
\hline Sodium $(\mathrm{mg} / \mathrm{l})$ & 2.4 & 2.2 & 2.8 & 2.3 & 0.6 & 3.6 & 2.62 & 1.2 & 4.6 \\
\hline Potassium (mg/l) & 0.1 & BDL & 0.3 & 0.1 & 0.01 & 0.2 & 0.15 & 0.02 & 0.24 \\
\hline Bicarbonate (mg/l) & 68 & 50 & 95 & 92 & 45 & 130 & 203 & 170 & 240 \\
\hline Chloride (mg/l) & 1.6 & 0.5 & 2.5 & 2.1 & 0.24 & 6 & 6.46 & 3.5 & 8.25 \\
\hline Sulphate (mg/l) & 7.5 & 2.8 & 15.2 & 9.6 & 2.64 & 18.6 & 11.5 & 7.6 & 16.2 \\
\hline Nitrate (mg/l) & 1.3 & BDL & 4.2 & 4.0 & 2.18 & 5.75 & 0.89 & 0.65 & 1.25 \\
\hline Silica $(\mathrm{mg} / \mathrm{l})$ & 0.6 & 0.2 & 0.8 & 0.7 & 0.17 & 1.19 & 1.38 & 0.62 & 1.88 \\
\hline Fluoride $(\mathrm{mg} / \mathrm{l})$ & 1.1 & 0.8 & 1.4 & 0.9 & 0.63 & 1.25 & 0.77 & 0.62 & 0.86 \\
\hline
\end{tabular}

$\mathrm{BDL}=$ Below detection limits.

mineralization. The TDS and electrical conductivity (EC) of the cold spring water samples ranged between $99-222 \mathrm{mg} / \mathrm{l}$ and $142-326 \mu \mathrm{S} / \mathrm{cm}$, respectively. However, the TDS and EC of the warm spring (Kongamnag) ranged from $307-425 \mathrm{mg} / \mathrm{l}$ and $442-530 \mu \mathrm{S} / \mathrm{cm}$, respectively. The lowest values of TDS were observed in late spring and summer, while the higher values were observed in winter. The seasonal variation in TDS in stream and spring waters may be attributed to the dilution of surface and groundwater by snow melting, which recharges the groundwater and surface water during late spring and summer, while increased residence time during winter allows for more waterrock interaction (Bhat et al. 2014).

\subsection{Major ions}

As expected for waters circulating through and/or over carbonate lithology, the hydrochemical facies found in the study area are $\mathrm{Ca}-\mathrm{HCO}_{3}$ and $\mathrm{Ca}-\mathrm{Mg}-$ $\mathrm{HCO}_{3}$. Most of the stream and spring water samples were dominated by $\mathrm{Ca}, \mathrm{Mg}$ and $\mathrm{HCO}_{3}$, which constitute over $85 \%$ of the major ions. $\mathrm{Ca}$ and $\mathrm{Mg}$ accounted for $\sim 88 \%$ and $\sim 80 \%$ of the total cation budget in the stream and spring water samples, respectively. $\mathrm{HCO}_{3}$ accounted for $\sim 89 \%$ of the total anion budget in most of the water samples. This indicates the carbonate weathering as the dominant source of the major ions. A cross plot of $\mathrm{Ca}+$ $\mathrm{Mg}$ vs. $\mathrm{HCO}_{3}$ (figure 2) suggests that the chemical evolution of the water in the catchment is characterized by the reaction of dissolved $\mathrm{CO}_{2}$ with the carbonate rocks, dissolving calcite and dolomite

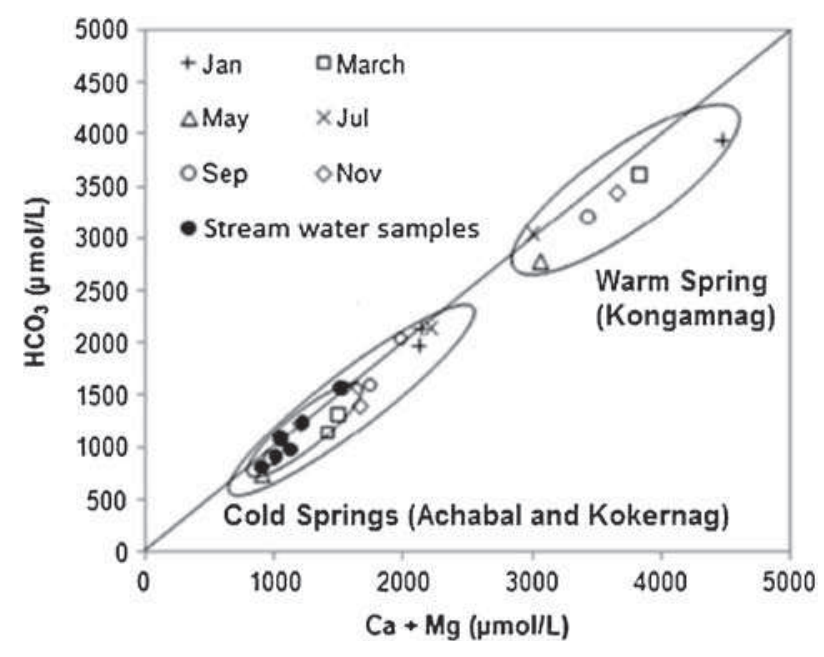

Figure 2. Cross plot of $(\mathrm{Ca}+\mathrm{Mg})$ vs. $\mathrm{HCO}_{3}$ showing how the chemistry of cold and warm karst springs relate to stream water chemistry. Note the warm water karst springs are chemically distinct from stream and cold karst springs.

in the aquifer and on the ground surface. The higher concentration of $(\mathrm{Ca}+\mathrm{Mg})$ and $\mathrm{HCO}_{3}$ in Kongamnag (figure 2) may be attributed to the warm temperature of the groundwater which has more capacity to dissolve the carbonate rock (Jeelani et al. 2011). All the waters drained by the carbonate aquifer have Ca concentration of 29-146 $\mathrm{mg} / \mathrm{l}, \mathrm{Mg}$ concentration of $4-20 \mathrm{mg} / \mathrm{l}$ and $\mathrm{HCO}_{3}$ concentration of $45-240 \mathrm{mg} / \mathrm{l}$. The concentration of $\mathrm{Ca}(35-45 \mathrm{mg} / \mathrm{l}), \mathrm{Mg}(1-9 \mathrm{mg} / \mathrm{l})$ and $\mathrm{HCO}_{3}(50-$ $95 \mathrm{mg} / \mathrm{l})$ in the stream water samples is lower indicating less residence time of the catchment waters to interact with the surface geology owing to the steep slopes but also to reduced water-rock contact 
Table 2. Summary of stable isotope analysis $\left(\delta^{18} O, \delta D\right)$ of precipitation, stream and spring water samples of Bringi watershed (Precip: precipitation; WM: weighed mean).

\begin{tabular}{|c|c|c|c|c|c|c|c|c|c|c|c|}
\hline \multirow[b]{2}{*}{ Station } & \multirow{2}{*}{$\begin{array}{l}\text { Station } \\
\text { type }\end{array}$} & \multirow{2}{*}{$\begin{array}{l}\text { Elevation } \\
\text { (m amsl) }\end{array}$} & \multicolumn{4}{|c|}{$\delta^{18} \mathrm{O}(\%)$} & \multicolumn{4}{|c|}{$\delta^{2} \mathrm{H}(\%)$} & \multirow{2}{*}{$\begin{array}{c}\text { Tritium } \\
\text { (TU) }\end{array}$} \\
\hline & & & Min & $\operatorname{Max}$ & Average & WM & Min & $\operatorname{Max}$ & Average & WM & \\
\hline Achabal & Precip. & 1656 & -10.0 & -2.1 & -4.8 & -5.4 & -0.6 & -12.6 & -26.2 & -29.4 & 13.29 \\
\hline Kokernag & Precip. & 1890 & -10.6 & -2.4 & -5.8 & -6.2 & -7.6 & -23.2 & -32.7 & -35.0 & 14.65 \\
\hline Pindabal & Precip. & 2110 & -10.4 & -3.2 & -6.6 & -6.7 & -6.5 & -15.7 & -34.4 & -34.9 & 16.89 \\
\hline Bringi & Stream & 2110 & -8.7 & -6.9 & -7.9 & -7.9 & -7.3 & -36.4 & -44.1 & -44.0 & 15.50 \\
\hline Achabal & Spring & 1656 & -8.6 & -6.6 & -7.8 & -7.8 & -7.3 & -40.9 & -44.0 & -44.5 & 13.19 \\
\hline Kokernag & Spring & 1890 & -8.9 & -7.2 & -8.2 & -8.2 & -0.3 & -40.7 & -45.7 & -45.8 & 15.48 \\
\hline Kongamnag & Spring & 1922 & -9.2 & -8.1 & -8.8 & -8.9 & -7.6 & -54.6 & -55.9 & -55.8 & 16.65 \\
\hline
\end{tabular}

surface and decreased $\mathrm{CO}_{2}$ content in river water. The concentration of $\mathrm{Na}(2.2-2.4 \mathrm{mg} / \mathrm{l})$ and $\mathrm{SiO}_{2}$ $(0.2-0.8 \mathrm{mg} / \mathrm{l})$ is low in stream and spring water samples with the exception of warm springs where $\mathrm{Na}$ content up to $4.6 \mathrm{mg} / \mathrm{l}$ and $\mathrm{SiO}_{2}$ content up to $1.9 \mathrm{mg} / \mathrm{l}$ is recorded. There is no significant correlation between $\mathrm{Si}, \mathrm{Na}, \mathrm{K}$ and $\mathrm{HCO}_{3}$ implying minimal weathering of silicate minerals. The concentration of $\mathrm{Cl}$ is lower $(0.2-6.0 \mathrm{mg} / \mathrm{l})$ in the stream and spring water samples except Kongamnag (3.5$8.3 \mathrm{mg} / \mathrm{l})$. The concentration of $\mathrm{NO}_{3}$ is lower in Kongamnag (0.6-1.3 mg/l) than the stream (up to $4.2 \mathrm{mg} / \mathrm{l}$ ) and spring water (up to $5.8 \mathrm{mg} / \mathrm{l}$ ) samples indicating the vulnerability of the Kokernag and Achabalnag to anthropogenic contamination. Kongamnag is a high altitude (about $1925 \mathrm{~m}$ amsl) spring, which may be recharged beyond the area of direct anthropogenic influence. All the waters of the study area have fluoride concentrations within the permissible limit for human consumption and range between 0.6 and $1.4 \mathrm{mg} / \mathrm{l}$. The concentration of most of the major ions in the stream water samples was found to be low during snow melting period (spring and summer) and high during winter when the snow melting is negligible and precipitation is in the form of snow.

\subsection{Stable isotopes}

\subsubsection{Precipitation}

The stable isotopic composition of precipitation (rainwater and fresh snow) showed a marked spatial and temporal variations (table 2). Measured $\delta^{18} \mathrm{O}$ and $\delta \mathrm{D}$ ranged from -2.1 to $-10.6 \%$ with a mean of $-5.8 \%$ and -12.59 to $-60.6 \%$ with a mean value of $-31.1 \%$, respectively. The samples were depleted in $\delta^{18} \mathrm{O}$ and $\delta \mathrm{D}$ isotopes at higher elevation and enriched during summer. Lowest values were observed in January (mean $\delta^{18} \mathrm{O}=-10.4 \%$; $\delta \mathrm{D}=-58.2 \%$ ) and enriched values were observed in July (mean $\delta^{18} \mathrm{O}=-2.1 \%$; $\delta \mathrm{D}=-12.6 \%$ ). The isotopic composition of precipitation showed a

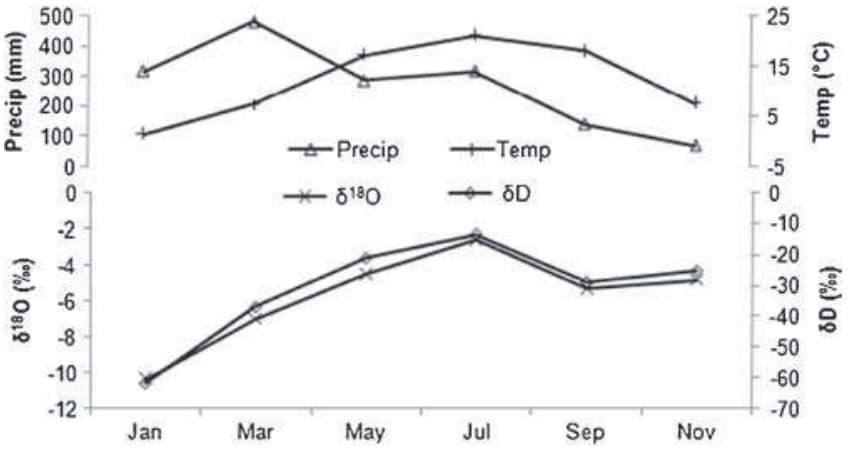

Figure 3. Relationship of average $\delta \mathrm{D}$ and $\delta^{18} \mathrm{O}$ of precipitation with temperature and precipitation.

very good correlation with temperature and precipitation $\left(r^{2}=0.97\right)$ (figure 3 ). Lower temperature and higher amount of precipitation yield precipitation with depleted isotopes (Clark and Fritz 1997). Craig (1961) observed the following correlation between stable isotope ratios of hydrogen and oxygen in precipitation, known as global meteoric water line (GMWL):

$$
\delta D=8 \times \delta^{18} \mathrm{O}+10 .
$$

The slope of the regression line is controlled by the ratio between isotope equilibrium fractionation factors of hydrogen and oxygen, while the intercept is controlled by the evaporation processes in the water vapour of the source region (Craig 1961). Later Rozanski et al. (1993) published the following GMWL, using more available data:

$$
\delta \mathrm{D}=(8.20 \pm 0.07) \times \delta^{18} \mathrm{O}+(11.27 \pm 0.65) .
$$

The regression equation between $\delta^{18} \mathrm{O}$ and $\delta \mathrm{D}$ (figure 4) for the Bringi watershed, known as local meteoric water line (LMWL), based on the amount weighed mean monthly samples is as follows:

$$
\delta \mathrm{D}=7.7 \times \delta^{18} \mathrm{O}+11.1\left(r^{2}=0.99\right) .
$$

The LMWL is almost close to LMWL of western Himalayas, $\delta \mathrm{D}=7.95 \times \delta^{18} \mathrm{O}+11.51$ (Kumar et al. 


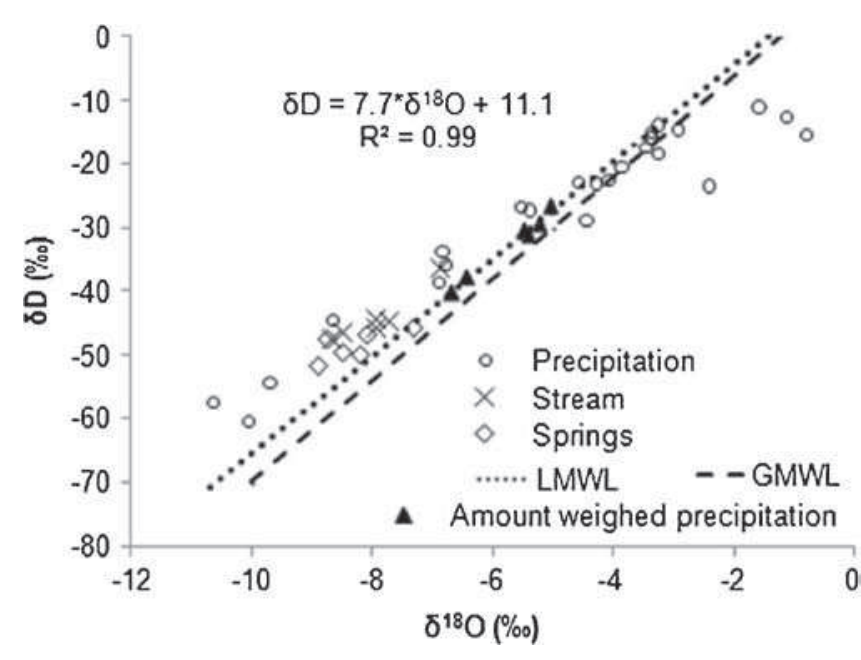

Figure 4. Local meteoric water line (LMWL) of Bringi watershed. GMWL is shown as dashed line for comparison.

2010) and GMWL, with a shallower slope and higher intercept than GMWL and shallower slope and lower intercept when compared to LMWL of western Himalayas. This could be attributed to the effect of evaporation and/or different sources of moisture. The effect of evaporation on the isotopic composition of precipitation is clear by plotting the $\delta^{18} \mathrm{O}$ and $\delta \mathrm{D}$ data (figure 4), which shows that some data points fall below the GMWL indicating the effect of temperature on precipitation during summer months. In winter, the data points fall above the GMWL reflecting enhanced moisture recycling.

\subsubsection{Springs}

Like streams, the stable isotope composition of the stream water samples showed a narrow spatial and temporal variation (table 2), with $\delta^{18} \mathrm{O}$ ranging from -6.6 to $-9.2 \%$ with a mean of $-8.3 \%$ and $\delta \mathrm{D}$ from -40.7 to $-57.6 \%$ with a mean value of $-48.5 \%$. Kongamnag was depleted in heavier isotopes (average $\delta^{18} \mathrm{O}=-8.8 \%$ and $\delta \mathrm{D}=$ $-56.0 \%$ ), while Achabalnag was enriched (average $\delta^{18} \mathrm{O}=-7.8 \%$ and $\delta \mathrm{D}=-44.0 \%$ ). The annual amplitude of $\delta^{18} \mathrm{O}$ variations in the karst springs was 1.16-1.97, which is similar to the Figeh and Kapuz karst springs (Kattan 1997) and karst springs of Meramec River basin (Fredrickson and Criss 1999), where the amplitude was about $1-2 \%$. Like streams, the spring water samples were most depleted in heavier isotopes in late spring season (May) with mean $\delta^{18} \mathrm{O}$ and $\delta \mathrm{D}$ values of $-8.87 \%$ and $-51.71 \%$, respectively and enriched in early autumn (September) with mean $\delta^{18} \mathrm{O}$ and $\delta \mathrm{D}$ values of $-7.3 \%$ and $-45.73 \%$ respectively (figure 5 ). The isotopic signature of spring water in May is,

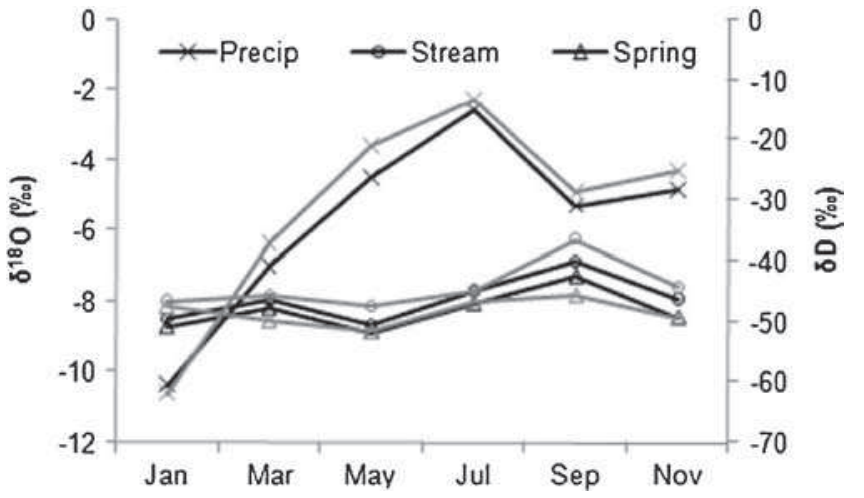

Figure 5. Average stable isotope composition of precipitation, stream and spring water samples showing their relationship. Black lines are for $\delta^{18} \mathrm{O}$ and grey lines are for $\delta \mathrm{D}$.

therefore, a representative of snow melting. Negligible snow melting and recharge, lower temperature and low spring discharges in winter (January) indicated the spring base flow contributed from the aquifer storage. The enriched spring discharges in September bears the enriched isotopic signatures of rainfall only. Hence, the isotopic signature of spring discharge during September reflects that of rainfall. The spring water samples also fall above the GMWL indicating negligible evaporation during the traverse through the geological material. More frequent and denser sampling in the catchment is needed to better understand and estimate the mean residence time of the various input parameters including snow melt, rain, base-flow, etc.

\subsubsection{Streams}

The stable isotope composition of the stream water samples showed a narrow temporal variation (table 2), with $\delta^{18} \mathrm{O}$ ranging from -6.8 to $-8.5 \%$ with a mean of $-7.8 \%$ and $\delta \mathrm{D}$ from -36.4 to $-47.3 \%$ with a mean value of $-44.1 \%$. The stream water samples were most depleted in heavier isotopes in late spring (May) season $\left(\delta^{18} \mathrm{O}=-8.5 \% 0\right.$ and $\delta^{2} \mathrm{H}=-47.33 \%$ ) and enriched in early autumn (September) season $\left(\delta^{18} \mathrm{O}=-6.8 \%\right.$ and $\delta \mathrm{D}=$ $-36.43 \%$ ). The temporal variability of isotopes in precipitation, with significantly depleted values in winter (January), is not reflected in the isotopic composition of stream samples. The streams were depleted in late spring season (May) not in winter, indicating the accumulation of depleted winter precipitation and the release of depleted snow melt during spring. Therefore, the melting of snow and ice accumulated during the preceding winter at higher altitudes dominantly control the stream flow in late spring season up to late summer, until the snow is fully melted. Thus, the isotopic signal 
of summer (July) precipitation which is enriched in the isotopes is not clearly reflected in the isotopic composition of streams (figure 5), although a slight enriched character is apparent. Due to less stream flow in autumn, the enriched isotopic signal of summer precipitation is clearly reflected in autumn. Negligible melting due to winter temperatures indicates the base-flow as the main contributor of runoff. Further study with more intense sampling (preferably weekly) is needed to understand better and assess the nature of precipitation isotope values lag in the catchment. All the stream water samples fall above the GMWL close to the winter precipitation values indicating a dominant role of winter precipitation in annual runoff of the stream and springs.

\subsubsection{Tritium}

The tritium concentration (table 2) of precipitation samples ranged from 13.3 to 16.9 TU with an average of $15.1 \mathrm{TU}$. High tritium values were observed in snow samples, while low tritium content was found in rain water during summer indicating the different sources of precipitation. The western disturbances originating from the Mediterranean Sea dominantly control the precipitation in winter while the local atmospheric circulation is the main source of rainfall during summer (Jeelani et al. 2010). Tritium concentration in streams and springs was similar and ranged from 14.3 to 16.7 TU at an average of $15.5 \mathrm{TU}$ and $11.44-16.6 \mathrm{TU}$ with a mean of $13.7 \mathrm{TU}$, respectively. The higher values are observed in spring season and lower values are observed in autumn season. Higher tritium in winter precipitation is reflected in streams and springs during spring season and lower tritium in rainfall is reflected in streams and springs during autumn season. These results corroborate with the stable isotope results discussed above that the stream flow in spring season is dominantly controlled by the melting of winter snow, while as in autumn season the flow is dominantly contributed from the rainfall.

\subsection{Discussion}

The area under investigation receives maximum precipitation in winter and early spring season and less precipitation in autumn season. However, the streams and springs have high flow in late spring season and low discharge in winter. The streams and springs showed almost similar response to precipitation and melting of snow (figure 6), the higher flow in the springs and the streams is observed in summer (July) and minimum discharge in winter (January). Hydrogeochemical and isotopic approaches have been used to delineate the recharge areas of the karst springs.

\subsubsection{Hydrogeochemical approach}

The results of the physico-chemical analysis of precipitation, streams and springs suggests that the karst springs except Kongamnag and the Bringi streams have almost similar chemical characteristics. TDS of the streams showed a good correlation with the springs with varied mineralization (figure 7 ), the high mineralization being associated with the thermal system of the Kongamnag. The temporal variation of TDS is similar in both streams and springs being lower in late spring (May) and higher in winter (January). Due to

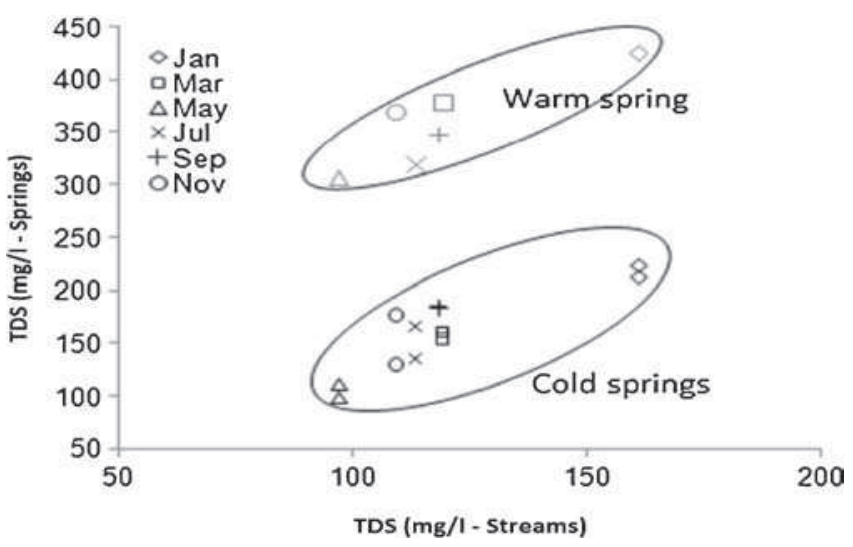

Figure 7. Correlation between TDS of streams and springs.

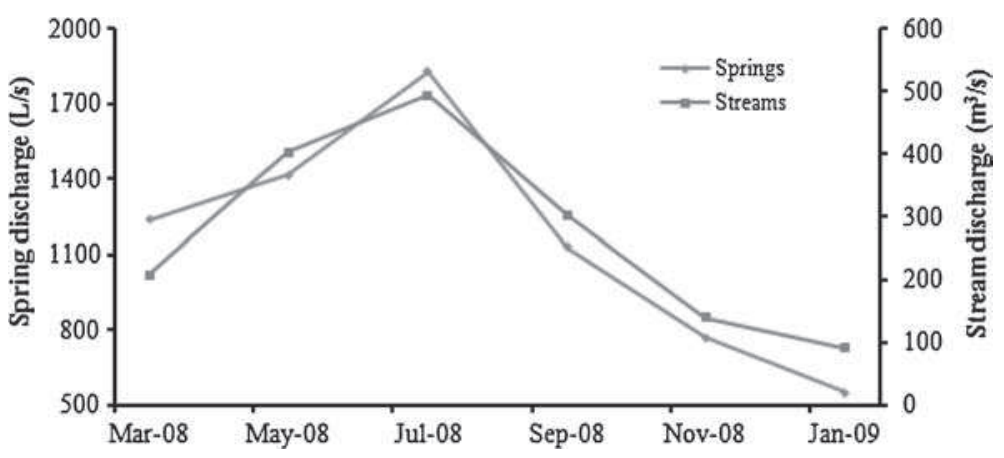

Figure 6. Relationship of average discharge of the springs with the stream flow. 
frost action and negligible groundwater recharge in winter, there is more residence time of groundwater which resulted in prolonged rock-water interaction and thus more dissolved solids are acquired by the spring water. The dissolved solids of the stream water in winter are dominantly controlled by the base flow. The distinct character of TDS in winter (January) suggested the maximum possible rock-water interaction. It is important to mention here that the springs in winter are saturated with respect to calcite $(\sim 1.1)$ and dolomite $(\sim 1.4)$. On the other hand, during late spring and summer seasons there is significant groundwater recharge and less time for water-rock interaction which results in low concentration of solutes in spring and stream water. The karst springs in most of the months are under saturated with respect to calcite and dolomite indicating the dynamic and aggressive nature of the karst waters to dissolve the host carbonate rock (Jeelani et al. 2011). Taking into account the similarities of the chemical characteristics between springs and streams, it seems that they share common catchments and there is a confirmed exchange of surface water and groundwater.

\subsubsection{Isotopic approach}

In the Bringi watershed, the oxygen and hydrogen isotope composition of the precipitation decreases with increase in altitude which is consistent with the well-known altitude effect (Dansgaard 1964; Smith et al. 1979; Ingraham and Taylor 1991). Precipitation is more depleted in isotopes at higher altitudes than precipitation at lower elevations. As a significant tool in delineating the recharge areas of aquifers (Longinelli and Selmo 2003), the isotopic gradient was calculated. A mean $\delta^{18} \mathrm{O}$

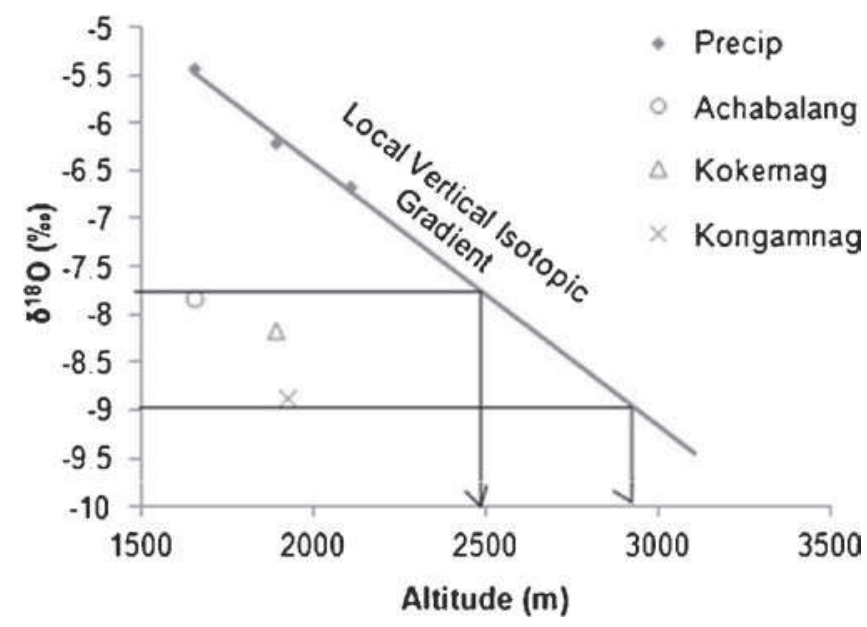

Figure 8. $\delta^{18} \mathrm{O}$ vs. altitude showing the inferred recharge elevations of the springs. altitude effect of $-0.27 \%$ per $100 \mathrm{~m}$ was estimated based on amount weighed mean annual isotopic composition of precipitation, which closely resemble the isotopic gradient $(-0.2 \%$ per $100 \mathrm{~m})$ in Liddar watershed of Kashmir Himalaya (Jeelani et al. 2010), altitude effect of precipitation $(-0.26 \%)$ in Switzerland (Siegenthaler and Oeschger 1980) and within the published values of $-0.15 \%$ to $-0.5 \% / 100 \mathrm{~m}$ increase in elevation (Clark and Fritz 1997; Yehdegho and Reichl 2002). The $\delta^{18} \mathrm{O}$ and $\delta \mathrm{D}$ value of groundwater commonly reflects the elevation and temperature of precipitation that infiltrates into the subsurface. Given the high relief of the study area $(\Delta=2400 \mathrm{~m})$ and strong isotopic variability, the altitude effect is a proper tool to determine the mean recharge altitude of the springs. With the help of local vertical isotopic gradient of precipitation (figure 8), the mean elevation of precipitation that recharged the aquifer was estimated. The inferred mean elevation of the recharge areas of the springs ranges between 2500 and $2900 \mathrm{~m}$ amsl (figure 8). The average estimated recharge elevation of the Kongamnag is higher ( $2900 \mathrm{~m}$ amsl) than Achabalnag $(\sim 2500 \mathrm{~m}$ amsl) and Kokernag (2650 m amsl). The annual weighed mean $\delta^{18} \mathrm{O}$ and $\delta \mathrm{D}$ of precipitation is enriched in heavier isotopes relative to the base-flow of the streams and springs, indicating the biased nature of the seasonal recharge which occurred from the precipitation with relatively depleted heavier isotopes, i.e., from the melting of winter precipitation (snow pack). The average annual weighed mean $\delta^{18} \mathrm{O}$ and $\delta \mathrm{D}$ of precipitation $\left(\delta^{18} \mathrm{O}=-6.1 \%\right.$; $\delta \mathrm{D}=-33.1 \%$ ) is also more enriched in isotopes, than the average annual weighed mean of the streams $\left(\delta^{18} \mathrm{O}=-7.9 \%\right.$; $\delta \mathrm{D}=-44.0 \%)$ and springs $\left(\delta^{18} \mathrm{O}=-8.3 \%\right.$; $\delta \mathrm{D}=$ $-48.7 \%$ ). This suggests that the effect of the evaporation is more on precipitation and the springs are recharged at higher elevations with more depleted values $(>2500 \mathrm{~m}$ amsl) as discussed above. There is a very good correlation $\left(r^{2}=0.97\right)$ between the seasonal isotope composition of streams and springs that indicates the streams and springs either share similar catchments or the springs are recharged by the streams. Further, the perennial nature of the streams, reduction of discharge along the Bringi stream due to sinking streams and sinkholes also support the Bringi stream as an ideal source of recharge. Based on the hydrological-, hydrochemical-, isotopic- and field-based evidences as discussed above, the stream and spring discharge/flow is controlled dominantly by the melting of winter snowpack and the Bringi stream as an ideal for recharge to occur. The results are further supported by the tracer tests carried out in Bringi stream at Adigam village (Coward et al. 1972). Bromine dye was inserted into a sinking stream 
at Adigam, about $14 \mathrm{~km}$ upstream from Achabalnag. The dye flowed out at Achabalnag within $48 \mathrm{~h}$ with a peak concentration after $68 \mathrm{~h}$. The dye tests confirm the hydrogeological connectivity between injection locations and the springs.

\section{Conclusion}

The karst springs in the Bringi watershed are characterized by low levels of mineralization with the exception of the warm spring (Kongamnag). The waters in the Bringi catchment were of the $\mathrm{Ca}-$ $\mathrm{HCO}_{3}$ and $\mathrm{Ca}-\mathrm{Mg}-\mathrm{HCO}_{3}$ type indicating carbonate lithology as a dominant source of solutes. The results suggest that the chemical evolution of the water in the stream and spring catchment is characterized by the reaction of dissolved $\mathrm{CO}_{2}$ with the carbonate rocks, dissolving calcite and dolomite in the aquifer and on the ground surface. The precipitation samples were more depleted in heavier isotopes at higher elevation and during winter, and enriched in heavier isotopes at lower elevations and during summer. The local meteoric water line (LMWL) for Bringi watershed based on the amount weighed monthly averages is $\delta \mathrm{D}=7.7$ * $\delta^{18} \mathrm{O}+11.1\left(r^{2}=0.99\right)$. The isotopic signature of winter precipitation is reflected in stream and spring water in late spring season and is, therefore, a representative of snow melting. The spring waters in September bear the enriched isotopic signatures of summer rainfall. The local vertical isotopic gradient of precipitation $(-0.27 \%$ per $100 \mathrm{~m}$ change in elevation) and the mean elevation of precipitation (2500-2900 $\mathrm{m}$ amsl) that recharged the aquifer were estimated. The study suggested that the stream and spring discharge/flow is controlled dominantly by the melting of winter snowpack and the Bringi stream; an ideal source of spring recharge, which is further supported by tracer testing.

\section{Acknowledgements}

The authors thank the scientists and staff at HIS, IAD, BARC, Mumbai and NIH, Roorkee for mass spectrometric analysis. The financial support from Board of Research in Nuclear Science (BRNS), Department of Atomic Energy, Government of India, is gratefully acknowledged. The comments and suggestions of the anonymous reviewers are highly appreciated.

\section{References}

Abbott M D, Lini A and Bierman P R $2000 \delta^{18} \mathrm{O}, \delta \mathrm{D}$ and ${ }^{3} \mathrm{H}$ measurements constrain groundwater recharge patterns in an upland fractured bedrock aquifer, Vermont, USA; J. Hydrol. 228 101-112.

Agarwal M, Gupta S K, Deshpande R D and Yadava M G 2006 Helium, radon and radiocarbon studies on a regional aquifer system of the north Gujarat-Cambay region, India; Chem. Geol. 228 209-232.

APHA 1998 Standard methods for the examination of water and waste; American Public Health Association, Washington DC.

Bhat N A, Jeelani Gh and Bhat M Y 2014 Hydrogeochemical assessment of groundwater in karst environments, Bringi watershed, Kashmir Himalayas, India; Curr. Sci. 106(7) 1000-1007.

Clark I D and Fritz P 1997 Environmental isotopes in hydrogeology; Lewis Publishers, Boca Raton.

Coward J M H, Waltham A C and Bowser R J 1972 Karst springs in the Vale of Kashmir; J. Hydrol. 16 213223.

Craig H 1961 Isotopic variation in meteoric waters; Science 133 1702-1703.

Dansgaard W 1964 Stable isotopes in precipitation; Tellus $16436-467$.

Epstein S and Mayeda T 1953 Variation of $\delta^{18} \mathrm{O}$ content in waters from natural sources; Geochim. Cosmochim. Acta 4 213-224.

Fontes J C, Letolle R, Oliver H and Ravoux B 1967 Oxygene 18 et tritium dans le basin d'Evian; In: Proceedings of symposium on isotopes in hydrology, International Atomic Energy Agency, Vienna, 401p.

Ford D and Williams P 1989 Karst Geomorphology and Hydrology; London: Chapman and Hall.

Fredrickson G C and Criss R E 1999 Isotope hydrology and time constants of the unimpounded Meramec River basin, Missouri; Chem. Geol. 157 303-317.

Gat J R 1971 Comments on the stable isotope method in regional groundwater investigations; Water Resourc. Res. 7 980-993.

Gonfiantini R 1981 The $\delta$-notation and the mass spectrometric measurement techniques; In: Stable isotope hydrology, deuterium and oxygen in the water cycle, International Atomic Energy Agency, Vienna.

Gonfiantini R, Gallo G, Payne B R and Taylor C B 1976 Environmental isotopes and hydrochemistry in groundwater of Gran Canaria; In: Interpretation of environmental isotope and hydrochemical data in groundwater hydrology, IAEA, Vienna, pp. 159-170.

Ingraham N L and Taylor B E 1991 Light stable isotope systematic of large-scale hydrologic regimes in California and Nevada; Water Resourc. Res. 27 77-90.

Jeelani G 2008 Aquifer response to regional climate variability in a part of Kashmir Himalaya in India; Hydrogeol. $J$. 16 1625-1633.

Jeelani G, Bhat N A and Shivanna K 2010 Use of $\delta^{18}$ O tracer to identify stream and spring origins of a mountainous catchment: A case study from Liddar watershed, western Himalaya, India; J. Hydrol. 393 257-264.

Jeelani G, Bhat N A, Shivanna K and Bhat M Y 2011 Geochemical characterization of surface water and spring water in SE Kashmir valley, western Himalayas: Implication to water-rock interaction; J. Earth Syst. Sci. 120(5) 921-932.

Jeelani G, Kumar S U, Bhat N A, Sharma S and Kumar B 2014 Variation of $\delta^{18} \mathrm{O}, \delta \mathrm{D}$ and ${ }^{3} \mathrm{H}$ in karst springs of south Kashmir, western Himalayas (India); Hydrol. Process., doi: 10.1002/hyp.10162.

Kattan Z 1997 Environmental isotope study of the major karst springs in Damuscus limestone aquifer system: Case of the Figeh and Barada springs; J. Hydrol. 193 161182. 
Kumar B, Rai S P, Kumar U S, Verma S K, Garg P, Kumar S V V, Jaiswal R, Purendra B K, Kumar S R and Pande N G 2010 Isotopic characteristics of Indian precipitation; Water Resourc. Res. 46 1-15.

Lee K S, Wenner D B and Lee I 1999 Using H- and O-isotopic data for estimating the relative contributions of rainy and dry season precipitation to groundwater: Example from Cheju Island, Korea; J. Hydrol. 222 65-74.

Longinelli A and Selmo E 2003 Isotopic composition of precipitation in Italy: a first overall map; J. Hydrol. 270 $75-88$.

McConville C, Kalin R M, Johnston H and McNeil G W 2001 Evaluation of recharge in a small temperate catchment using natural and applied $\delta^{18} \mathrm{O}$ profiles in the unsaturated zone; Ground Water 39 616-624.

Middlemiss C S 1910 A revision of Silurian-Triassic sequence of Kashmir; Rec. Geol. Surv. India 40 206-260.

O'Driscoll M A, DeWalle D R, McGuire K J and Gburek W J 2005 Seasonal ${ }^{18} \mathrm{O}$ variations and groundwater recharge for three landscape types in central Pennsylvania, USA; J. Hydrol. 303 108-124.

Price R M and Swart P K 2006 Geochemical indicators of groundwater recharge in the surficial aquifer system,
Everglades National Park, Florida, USA; In: Perspectives on karst geomorphology, hydrology, and geochemistry A tribute volume to Derek C Ford and William B White. (eds) Harmon R S and Wicks C, Geol. Soc. Am. Spec. Paper 404 251-266.

Rozanski K, Aruguás-Aruguás L and Ganfiantini R 1993 Isotopic patterns in modern global precipitation; Geophys. Monograph 78 1-36.

Siegenthaler U and Oeschger H 1980 Correlation of ${ }^{18} \mathrm{O}$ in precipitation with temperature and altitude; Nature $\mathbf{2 8 5}$ 314-317.

Smith D I 1993 The nature of karst aquifers and their susceptibility to pollution; Catena Suppl. 25 41-58.

Smith G I, Friedman I, Klieforth H E and Hardcastle K 1979 Aerial distribution of deuterium in eastern California precipitation; J. Appl. Meteorol. 18 172-188.

Wadia D N 1975 Geology of India; Tata McGraw Hill, New Delhi.

Yehdegho B and Reichl P 2002 Recharge areas and hydrochemistry of carbonate springs issuing from Semmering Massif, Austria, based on long-term oxygen-18 and hydrochemical data evidence; Hydrogeol. J. 10 628642. 